\title{
HUBUNGAN MOTIVASI KERJA, KETERAMPILAN KERJA DAN PERILAKU KOGNITIF PEGAWAI TERHADAP PENGEMBANGAN KARIR DI SATUAN POLISI PAMONG PRAJA KECAMATAN KEBAYORAN BARU KOTA ADMINISTRASI JAKARTA SELATAN
}

\author{
Nourma Fransiskha S. \\ n.fransiskha@gmail.com \\ Manahan Tampubolon \\ manahan_tb@yahoo.com \\ Erni Murniarti \\ Erni.murniarti@uki.ac.id
}

\begin{abstract}
ABSTRAK
Tujuan dari penelitian ini adalah untuk menganalisis seberapa jauh variabel motivasi kerja, keterampilan kerja dan perilaku kognitif pegawai berhubungan terhadap pengembangan karir pada Satuan Polisi Pamong Praja Kecamatan Kebayoran Baru Kota Administrasi Jakarta Selatan, baik secara parsial maupun simultan.

Untuk mengetahui hubungan variabel independen motivasi kerja, keterampilan kerja dan perilaku kognitif terhadap pengembangan karir pegawai ditentukan oleh persamaan regresi sederhana dan regresi berganda. Untuk mengetahui signifikansi, data yang diperoleh dari angket diuji validitasnya melalui validitas, reliabilitas, normalitas, linieritas dan homogenitas. Metode analisis menggunakan uji $\mathrm{t}$ dan uji $\mathrm{F}$ dengan pemrosesan data menggunakan software SPSS versi 23.0.

Hasil penelitian menunjukkan bahwa (1) Terdapat hubungan antara motivasi kerja dengan pengembangan karir. Dari hasil analisis uji t pada tabel , diperoleh $\mathrm{t}_{\text {hitung }}$ sebesar 2,938 dan signifikansi nilai $\mathrm{t}$ sebesar 0,005 artinya terdapat hubungan yang positif antara variabel motivasi kerja dan pengembangan karir pegawai karena nilai signifikansi $t{ }_{\text {hitung }}<$ alpha $(0,05),(2)$ terdapat hubungan antara keterampilan kerja terhadap pengembangan karir. Dari hasil analisis uji t pada tabel, diperoleh $\mathrm{t}$ hitung sebesar 5,123 dan signifikansi nilai t sebesar 0,000 artinya terdapat hubungan yang positif antara variabel keterampilan kerja dan pengembangan karir pegawai karena nilai signifikansi $t$ hitung < alpha $(0,05)$, (3) terdapat hubungan antara perilaku kognitif terhadap pengembangan karir. Dari hasil analisis uji t pada tabel, diperoleh $\mathrm{t}_{\text {hitung }}$ sebesar 4,811 dan signifikansi nilai $\mathrm{t}$ sebesar 0,000 artinya terdapat hubungan yang positif antara variabel perilaku kognitif dan pengembangan karir pegawai karena nilai signifikansi $t_{\text {hitung }}$ <alpha $(0,05)$, (4) diketahui nilai Sig. adalah sebesar 0,000. Karena nilai Sig. < 0,05, maka sesuai dengan dasar pengambilan keputusan dalam uji $\mathrm{F}$ dapat disimpulkan bahwa hipotesis diterima atau dengan kata lain motivasi kerja (X1), keterampilan kerja (X2) dan perilaku kognitif (X3) secara simultan berhubungan terhadap pengembangan karir (Y).
\end{abstract}

Kata Kunci: Motivasi Kerja, Keterampilan Kerja, Perilaku Kognitif dan Pengembangan Karir. 


\section{A. PENDAhuluan}

\section{LATAR BELAKANG MASALAH}

Secara tradisional kebanyakan pengembangan karir adalah sebagai bagian dari Pengembangan Sumber Daya Manusia di perusahaan dan atau organisasi masih atas dasar kekeluargaan, kedekatan, persahabatan dan kepentingan pribadi. Belum atas dasar kompetensi dan kebutuhan. Seringkali perjalanan karir seseorang yang ditempatkan menjadi pegawai masih tergantung pada nasib baik saja. Dan karena belum siap menapaki jenjang karir atau tidak dipersiapkan terlebih dahulu jenjang karirnya menyebabkan pegawai menjadi tidak efisien dan tidak efektif dalam melalui jenjang jenjang karirnya.

(Hall and Goodale:1986) mengungkapkan bahwa pengembangan karir (career development) telah menjadi perhatian pegawai dalam kehidupan organisasi masa kini. Lebih lanjut di sebagian besar organisasi pengembangan karir pegawai telah menjadi permasalahan kepegawaian yang membutuhkan perhatian khusus dan program pengembangan karir mulai menjamur di hampir semua organisasi. Dalam hal ini yang dimaksud dengan pengembangan karir adalah suatu proses dalam hal mana individu dan organisasi melakukan penilaian terhadap kelebihan dan kelemahan serta perjalanan rencana karir pegawai dalam organisasi. Pendapat tersebut diatas didukung adanya kecenderungan terhadap terjadinya pergeseran pendekatan pengembangan karir dan pendekatan karir yang bersifat tradisional menuju pendekatan karir modern dengan menekankan pada perspektif yang lebih global. (Noe : 1999) menggambarkan bahwa pengembangan karir tradisional menekankan aspek know how yang berarti bahwa seseorang dituntut untuk mempunyai keahlian yang mumpuni dan pengetahuan yang ditujukan untuk memberikan suatu pelayanan atau menghasilkan suatu produk. Sedangkan dalam pendekatan karir modern seorang diharapkan mempunyai aspek know why yang berarti memahami suatu perusahaan dan budaya sehingga dapat membangun dan menggunakan pengetahuan serta keahlian yang dapat membantu usaha, serta mempunyai pemahaman know whow yang berarti pemahaman akan hubungan bahwa pekerja mempunyai signifikansi terhadap keberhasilan usaha. Pola pergeseran pengembangan karir terjadi karena adanya tuntutan yang bersifat intern dan bersifat ekstern. Pola pengembangan karir tradisional digambarkan lebih cenderung pada posisi hirarkis, kewenangan dan tanggung jawab serta kompensasi. Pola ini telah bergeser ke arah pengembangan karir modern, yang digambarkan bahwa pengembangan karir modern ditujukan untuk membina pegawai dengan memberikan kesempatan untuk memilih kepentingan pribadi, keahlian, serta tersedianya informasi untuk mencari pengalaman dalam hal pengembangan karir. 
Dalam konteks aktual, pengembangan karir menjadi salah satu aspek yang penting untuk organisasi yang sedang berubah. Menurut (London:1992), organisasi yang sedang berubah atau organisasi yang sedang menghadapi tantangan perubahan baik dari dalam maupun dari luar, membutuhkan suatu paradigma pengembangan karir modern. Pendekatan tersebut hendaknya menekankan pada pendekatan yang memberikan kesempatan kepada individu untuk menigkatkan pengetahuan dan keahlian baru, bersifat proaktif, sistematis, self-assesment serta pemberian motivasi. Pergeseran pendekatan pengembangan karir tidak hanya melanda para sektor bisnis saja namun juga mulai merambah pada sektor publik. Hal ini disebabkan bahwa perubahan yang cepat dan fundamental tengah terjadi di segala bidang sehingga menuntut kesiapan dan kesigapan organisasi publik untuk beradaptasi.

Pengembangan karir dan pemanfaatan sumber daya manusia merupakan kebutuhan organisasi, menyatakan bahwa pegawai mereka adalah aset yang paling berharga. Meskipun demikian, pegawai yang ditempatkan pada posisi yang tidak tepat dan mengalami frustasi untuk tumbuh dan berkembang merugikan organisasi.

Munculnya fenomena penurunan jabatan dan kemangkiran pegawai (demosi), perpindahan pegawai yang dikenal dengan mutasi serta adanya suatu promosi pegawai merupakan bentuk pengembangan karir. Dilihat dari pentingnya kebijakan instansi tersebut diperlukan rumusan untuk mengatur administrasi dari semua jenis pemindahan pegawai.

Menurut pendapat (Handoko, 1983 : 130) implementasi rencana karir memerlukan pengembangan karir. Pengembangan karir merupakan upaya pribadi seorang pegawai untuk mencapau suatu rencana karir. Oleh karena itu dalam suatu organisasi para anggotanya mengharapkan suatu pola kemajuan yang berdasarkan atas apa yang mereka dapatkan dan kerjakan. Apalagi seorang pegawai ingin diberi kesempatan yang luas ke berbagai jabatan serta dipromosikan dalam garis karir tertentu yang menjadi impian mereka.

Pengembangan karir dapat dilihat dari peningkatan karir seseorang dari tingkat yang satu ke tingkat yang lainnya. Pengembangan karir sebagai sebuah cara untuk menyakinkan perusahaan untuk mendapatkan kemampuan yang terbaik dari pegawainya sehingga mereka mampu untuk jenjang yang berikutnya yang lebih baik. Pengelolaan harus dilakuan dengan sebaik mungkin dan dikembangkan sebab organisasi dapat mencapai tujuan yang diharapkan. Dengan adanya pengelolaan dan pengembangan karir akan dapat meningkatkan efektifitas dan kreativitas sumber daya manusia dalam upaya mendukung organisasi untuk mencapai suatu tujuan (Robin : 2003). Melalui perencanaan karir, setiap individu mengevaluasi kemampuan dan minatnya sendiri, mempertimbangkan kesempatan karir alternatif, menyusun tujuan karir, dan merencanakan aktivitas-aktivitas pengembangan praktis. Fokus utama dalam perencanaan karir haruslah sesuai antara tujuan pribadi dan kesempatan - kesempatan yang secara realistis tersedia (Mondy : 1993). 
Selain itu pengembangan karir adalah tidak lebih tanggung jawab organisasinya, tetapi pegawai terus akuntabilitas untuk mengelola karir mereka sendiri, oleh sebab itu keterampilan dan kemampuan pegawai perlu didefinisiksan untuk tetap berharga bagi organisasi mereka. Pengembangan karir adalah tentang pengembangan pegawai yang menguntungkan kedua individu dan organisasi, dan merupakan proses yang kompleks Puah dan (Anthram : 2006) (Leibowitz et al:1986) berpendapat bahwa pengembangan karir melibatkan terorganisir, diformalkan, direncanakan upaya untuk mencapai keseimbangan antara karir individu kebutuhan dan persyaratan tenaga kerja organisasi. Perencanaan karir merupakan suatu proses dimana individu dapat mengidentifikasi dan mengambil langkah - langkah untuk mencapai tujuan karirnya (Simamora:2001). Perencanaan karir meliputi kegiatan pengumpulan informasi tentang peluang karir, mencari kinerja dan kompetensi umpan balik melalui jaringan dan tindakan (Sturges et al:2005). Gagasan perencanaan dan pengembangan karir inisiatif mendorong efektivitas organisasi tergantung pada kemampuan organisasi untuk pegawai peningkatan tanggung jawab untuk pertumbuhan mereka sendiri karir dan pengembangan (Martin et al 2001). Selain itu, sistem pengembangan karir memungkinkan organisasi untuk memanfaatkan kekayaan mereka bakat di rumah untuk perekrutan dan promosi dengan cara mencocokkan keterampilan, pengalaman, dan ambisi karyawan dengan kebutuhan organisasi.

Sumber Daya Manusia (SDM) merupakan faktor utama yang menentukan keberhasilan organisasi karena manusia merupakan sumber daya yang potensial dan sumber kekuatan untuk menggerakan aktivitas organisasi dan mengendalikan elemen organisasi lainnya, seperti modal, material dan teknologi sehingga peran dan fungsinya tidak dapat digantikan oleh sumber daya lainnya, tanpa adanya sumber daya manusia yang memadai, kegiatan organisasi tidak akan berjalan dengan baik.

Dimensi pokok sisi sumber daya adalah kontribusinya terhadap organisasi, sedangkan dimensi pokok manusia adalah perlakuan kontribusi terhadapnya yang pada gilirannya akan menentukan kualitas dan kapabilitas hidupnya. Dengan kata lain sumber daya manusia harus diartikan sebagai sumber dari kekuatan yang berasal dari manusia-manusia yang dapat didayagunakan oleh organisasi sehingga harus diperhatikan dengan segala kebutuhannya. Oleh karena itu, suatu organisasi harus memiliki strategi, kebijakan, dan program kerja yang sesuai dengan kemampuan SDM dalam mengoperasikan alat kerja untuk mencapai sasaran kerja.

Keberhasilan suatu organisasi sangat erat kaitannya dengan kualitas kinerja para pegawainya. Tujuan organisasi akan dapat dicapai melalui kinerja yang positif dari pegaainya, sebaliknya organisasi akan menghadapi hambatan dalam pencapaian tujuan manakala kinerja para pegawainya tidak efektif dalam arti tidak dapat memenuhi tuntutan pekerjaan yang diinginkan oleh organisasi.

Konsep karir adalah konsep yang netral (tidak berkonotasi positif atau negatif). Karena itu karir ada yang baik, ada pula karir yang kurang baik. Ada 
perjalanan karir yang lambat, ada pula yang cepat. Tetapi, tentu saja semua orang mendambakan memiliki karir yang baik dan bila mungkin bergulir dengan cepat. Karir dapat diletakkan dalam konteks organisasi secara formal, tetapi karir dapat pula diletakkan dalam konteks yang lebih longgar dan tidak formal. Dalam kaitan arti yang terakhir ini, kita biasa mengatakan, misalnya, "karir si A sebagai pelukis cukup baik" dan si B mengakhiri karirnya di bidang politik secara baik", dan sebagainya.

Dalam organisasi swasta, pada umumnya bagian personalia yang berperan menyusun dan menyesuaikan rencana karir individu disesuaikan dengan kebutuhan organisasi. Berbeda dengan organisasi pemerintah dalam penyusunan perencanaan karir untuk pengembangan karir disesuaikan dengan peraturan. Dimana sering terbentur dengan yang namanya peraturan sehingga menimbulkan pro dan kontra. Apakah hal yang seperti itu akan berlangsung selamanya. Bagaimana dengan pegawai yang mempunyai kemampuan lebih, tetapi kurang diperhatikan.

Seperti di lingkungan Pegawai Negeri Sipil (PNS) senioritas masih sering menjadi acuan, disamping itu juga ada yang disebut dengan Daftar Penilaian Pelaksanaan Pekerjaan yang dikenal dengan DP3. Padahal kalau dilihat DP3 tolak ukurnya kurang jelas. Apakah tidak ada pola lain yang dapat dijadikan acuan untuk mengembangkan karir pegawai? Sebab pada dasarnya pengembangan karir itu merupakan tanggung jawab individu itu sendiri. Di dalam lingkungan PNS dalam menghadapi era globalisasi, melihat pentingnya perencanaan karir yang dilakukan individu maupun organisasi. Apakah rencana tersebut hanya sekedar rancana tetapi pelaksanaannya nihil. Apabila mengamati di instansi pemerintah, meskipun sudah ada peraturan yang mengatur tetapi masih terjadi penyimpangan-penyimpangan. Bahkan peraturan sendiri kadang-kadang menjadi momok bagi pegawai.

Secara umum yang mempengaruhi karir seseorang adalah: (1) Keluarga; (2) Lingkungan; (3) Pendidikan; (4) Saran-saran mengenai karir dari sumber formal, misalnya dari pusat tenaga kerja, dan lain sebagainya; (5) Peran pegawai itu sendiri; para pegawai saat ini lebih terlibat dalam penentuan karirnya di perusahaan sebagai akibat dari kebijaksanaan pemerintah di bidang ketenaga kerjaan.

Manajemen karir adalah proses pengelolaan karir pegawai yang meliputi tahapan kegiatan perencanaan karir, pengembangan dan konseling karir, serta pengambilan keputusan karir. Manajemen karir melibatkan semua pihak termasuk pegawai yang bersangkutan dengan unit tempat si pegawai bekerja, dan organisasi secara keseluruhan. Oleh karena itu manajemen karir mencakup area kegiatan yang sangat luas. Dalam penulisan ini tahapan yang akan dibahas adalah tentang perencanaan dan pengembangan karir.

Pengembangan karir adalah proses mengidentifikasi potensi karir pegawai, dan materi serta menerapkan cara-cara yang tepat untuk mengembangkan potensi tersebut. Secara umum, proses pengembangan karir dimulai dengan mengevaluasi kinerja pegawai. Proses ini lazim disebut sebagai penilaian kinerja (performance appraisal). Dari hasil penelitian kinerja ini kita 
mendapatkan masukan yang menggambarkan profil kemampuan pegawai (baik potensinya maupun kinerja aktualnya). Dari masukan inilah kita mengidentifikasi berbagai metode untuk mengembangkan potensi yang bersangkutan.

Pengembangan karir dapat dipengaruhi oleh beberapa hal berikut: peran atasan/manajer, peran organisasi, pelatihan, pihak luar. Pertolongan dalam pengembangan karir pegawai dapat diperoleh dari berbagai sumber, misalnya institusi atau konsultan pendidikan atau departemen tenaga kerja.

Hal lain yang berkaitan dengan pengembangan karir adalah promosi. Promosi adalah peluang bagi pengembangan karir seorang pegawai. Kebijakan organisasi dalam hal promosi sangat penting bagi pegawai yang menginginkan karirnya berkembang. Promosi harus bijaksana, terbuka dan fleksibel, yaitu responsif terhadap kebutuhan individual. Setiap promosi memiliki faktor resiko bagi organisasi maupun bagi individual. Makin tinggi frekuensi pekerjaan, makin besar faktor resikonya, kemungkinan pemberian promosi yang salah dapat terjadi. Oleh karena itu diharapkan promosi pegawai disesuaikan dengan tingkat kompetensinya.

Dari penggambaran diatas maka penelitian ini berusaha menjelaskan bagaimana perencanaan dan pengembangan karir pegawai pada Satuan Polisi Pamong Praja Kecamatan Kebayoran Baru Kota Administrasi Jakarta Selatan.

\section{Perumusan Masalah}

Berdasarkan latar belakang masalah yang telah diuraikan, maka masalah penelitian ini dapat dirumuskan sebagai berikut:

1. Apakah terdapat hubungan motivasi kerja terhadap pengembangan karir di Satuan Polisi Pamong Praja Kecamatan Kebayoran Baru Kota Administrasi Jakarta Selatan.

2. Apakah terdapat hubungan keterampilan kerja terhadap pengembangan karir di Satuan Polisi Pamong Praja Kecamatan Kebayoran Baru Kota Administrasi Jakarta Selatan.

3. Apakah terdapat hubungan perilaku kognitif terhadap pengembangan karir di Satuan Polisi Pamong Praja Kecamatan Kebayoran Baru Kota Administrasi Jakarta Selatan.

4. Apakah terdapat hubungan secara bersama-sama antara motivasi kerja, keterampilan kerja dan perilaku kognitif dengan pengembangan karir di Satuan Polisi Pamong Praja Kecamatan Kebayoran Baru Kota Administrasi Jakarta Selatan.

\section{Tujuan Penelitian}

Tujuan yang ingin diketahui dalam penelitian ini secara umum adalah untuk mengetahui hubungan antara motivasi kerja, keterampilan kerja dan perilaku kognitif dengan pengembangan karir.

\section{B. METODE PENELITIAN}


Penelitian ini menggunakan metode deskriptif kuantitatif berupa studi regresi. Metode deskriptif adalah metode penelitian yang berusaha untuk mencari penyelesaian masalah yang ada sekarang berdasarkan data-data yang dikumpulkan. Metode regresi adalah penelitian yang digunakan untuk menetapkan besarnya hubungan antara variabel-variabel.

\section{Rancangan Penelitian}

Variabel bebas dalam penelitian ini adalah motivasi kerja, keterampilan kerja dan perilaku kognitif, sedangkan variabel terikatnya adalah pengembangan karir.

Desain Penelitian ini dapat digambarkan sebagai berikut :

\section{Gambar 1: Hubungan Antara Variabel}

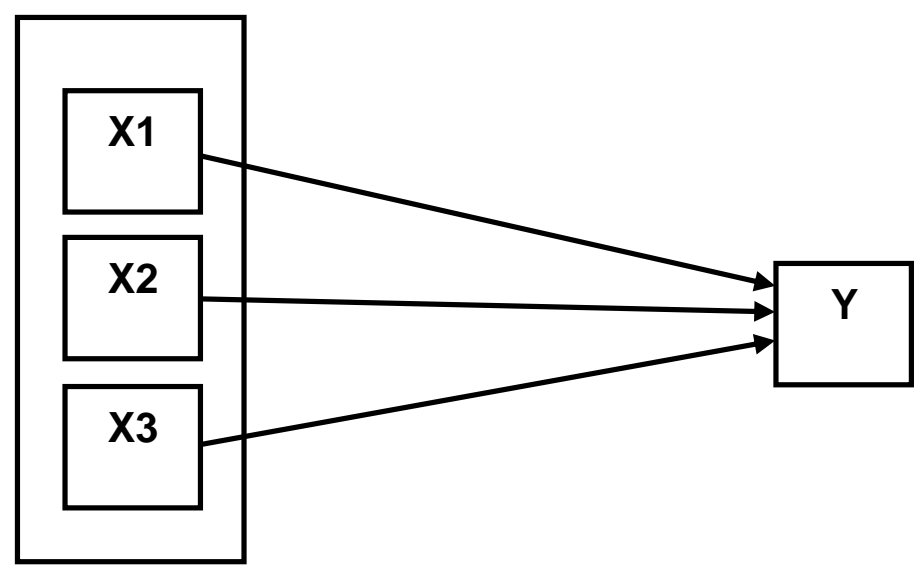

Keterangan:

Y : Pengembangan karir

$\mathrm{X} 1$ : Motivasi kerja

$\mathrm{X} 2$ : Keterampilan kerja

X3 : Perilaku kognitif

\section{Variabel Penelitian}

Variabel penelitian adalah segala sesuatu yang dapat mengklasifikasikan objek pengamatan ke dalam dua atau lebih kelompok. Variabel penelitian dapat dibedakan atas dua variabel yaitu variabel bebas yang disebut variabel penyebab dan variabel terikat yang disebut variabel terpengaruh. Variabel dalam penelitian ini terdiri dari dua macam yaitu:

1. Variabel Bebas

Variabel bebas adalah variabel yang memengaruhi variabel terikat. Variabel bebas dalam penelitian ini adalah Motivasi Kerja $\left(\mathrm{X}_{1}\right)$, Keterampilan Kerja $\left(\mathrm{X}_{2}\right)$ dan Perilaku Kognitif (X3).

2. Variabel Terikat 
Variabel terikat adalah variabel yang diukur untuk mengetahui besarnya pengaruh ataupun hubungan dengan variabel bebas. Variabel terikat dalam penelitian ini adalah Pengembangan Karir (Y).

\section{Teknik Pengambilan Sampel}

1. Populasi

Menurut Sugiyono (2012:90-91) populasi adalah wilayah generalisasi yang terdiri atas objek atau subjek yang mempunyai kualitas dan karakteristik tertentu yang ditetapkan oleh peneliti untuk dipelajari dan kemudian ditarik kesimpulannya, sedangkan sampel adalah bagian dari jumlah atau karakteristik tertentu yang dimiliki populasi. Populasi yang digunakan dalam penelitian ini adalah pegawai. Satuan Polisi Pamong Praja Kecamatan Kebayoran Baru Kota Administrasi Jakarta Selatan dengan golongan kepegawaian dua II (dua).

2. Sampel

Sampel yang dipilih sebagai responden dalam penelitian adalah sebanayak 50 orang responden dari total populasi di Satuan Polisi Pamong Praja Kecamatan Kebayoran Baru Kota Administrasi Jakarta Selatan. Berdasarkan pertimbangan bahwa pegawai yang menduduki level ini dalam hal ini golongan dua menduduki jabatan level manajemen menengah dan bawah memiliki peranan peranan yang besar dalam mengalokasikan sumber daya. Selanjutnya berdasarkan pertimbangan bahwa pegawai yang menduduki jabatan level pelaksana ini memiliki permasalahan yang sama atau gejolak di dalam pengembangan karir.

3. Teknik Sampling

Sampel dalam penelitian ini dipilih secara kuota. Sampling kuota (quota sampling) adalah teknik sampling yang menentukan jumlah sampel dari populasi yang memiliki ciri tertentu sampai jumlah kuota yang diinginkan (Suryana, 2015: 254). Untuk sampel uji coba, peneliti menggunakan 50 responden pegawai golongan II (dua) Satuan Polisi Pamong Praja Kecamatan Kebayoran Baru Kota Administrasi Jakarta Selatan dari total jumlah (populasi) sebanyak 71 pegawai.

\section{Teknik Pengumpulan Data}

Teknik pengumpulan data merupakan kegiatan untuk memperoleh data dari responden yang ditentukan dalam penelitian ini sehingga dapat dikumpulkan menjadi hasil yang dapat di uji kebenarannya. Analisis data dilakukan untuk data yang mengelola agar hasil yang diteliti bersifat akurat dan memuaskan, Teknik Pengumpulan data dalam penelitian ini adalah dengan menyusun pertanyaan atau pernyataan dalam bentuk angket (kuesioner). Angket ini di gunakan sebagai alat dalam penelitian ini yang 
dibagikan kepada responden yang sudah ditentukan atau kepada sampel penelitian.

Angket merupakan alat yang digunakan dalam penelitian ini untuk mendapatkan data-data yang di inginkan melalui sampel penelitian. Kuesioner penelitian ini disusun dengan Skala likert yaitu :

$$
\begin{array}{rlr}
\mathrm{SP} / \mathrm{SS} & =\text { Sangat Puas/ Sangat Setuju } & \text { diberi skor }=4 \\
\mathrm{P} / \mathrm{S} & =\text { Puas } / \text { Setuju } & \text { diberi skor }=3 \\
\mathrm{KP} / \mathrm{KS}= & \text { Kurang Puas/ Kurang Setuju } & \text { diberi skor }=2 \\
& \text { TP/TS = Tidak Puas/ Tidak Setuju } & \text { diberi skor }=1
\end{array}
$$

Penyebaran angket tersebut selaras responden tanpa rasa khawatir apabila responden memberika jawaban yang tidak sesuai dengan kenyataan dalam pengisian daftar pernyataan dan pernyataan (Riduan, 2008:26). Untuk mengukur instrumen, peneliti menggunakan Skala Likert. Skala Likert digunakan untuk mengukur sikap, pendapat, dan persepsi seseorang atau sekelompok orang tentang fenomena sosial (Sugiyono, 2008:134). Oleh karena itu Skala likert ini untuk mengetahuin jawaban atau nilai dari setiap pernyatan yang dibuat oleh peneliti sehingga dapat didapat nilai statistik dari angket yang di bagikan kepada sampel penelitian.

Sebelum melakukan penelitian, peneliti melakukan uji validitas dan reliabilitas masing-masing instrumen. Reliabilitas adalah kualitas yang menunjukkan kemantapan (consistency), ekuivalensi; atau stabilitas dari suatu pengukuran yang dilakukan, sedangkan validitas adalah kualitas yang menunjukkan kesesuaian antara alat pengukur dengan apa yang diukur. Uji instrumen ini dilakukan untuk memperoleh bukti mengenai ketepatan dan kecermatan alat ukur dalam melakukan fungsi ukurnya. Uji instrumen ini dilakukan untuk memperoleh bukti mengenai ketepatan dan kecermatan alat ukur dalam melakukan fungsi ukurnya.

\section{HASIL PENELITIAN}

a. Uji Hubungan motivasi kerja $\left(X_{1}\right)$ terhadap pengembangan karir (Y)

Tabel 2. Hasil Analisis Regresi Linier Sederhana Motivasi Kerja Terhadap Pengembangan Karir

\section{Coefficients $^{\mathrm{a}}$}

\begin{tabular}{|l|l|l|l|l|l|}
\hline \multirow{2}{*}{ Model } & \multicolumn{2}{|l|}{$\begin{array}{l}\text { Unstandardized } \\
\text { Coefficients }\end{array}$} & $\begin{array}{l}\text { Standardized } \\
\text { Coefficients }\end{array}$ & & \\
\cline { 2 - 4 } & $\mathrm{B}$ & Std. Error & Beta & $\mathrm{t}$ & Sig. \\
\hline 1 & 19.414 & 5.820 & & 3.336 & .002 \\
\hline
\end{tabular}




\begin{tabular}{|l|l|l|l|l|l|}
\hline $\begin{array}{l}\text { Motivasi Kerja } \\
(\mathrm{X} 1)\end{array}$ & .471 & .160 & .390 & 2.938 & .005 \\
\hline
\end{tabular}

a. Dependent Variable: Pengembangan Karir (Y)

Sumber: data kusioner diolah dengan SPSS

Dari hasil tersebut dapat dismpulkan bahwa korelasi antara motivasi kerja dan pengembangan karir pegawai signifikan. Artinya persamaan regresi $\hat{Y}$ $=19,414+0,471 X_{1}$ dapat digunakan sebagai alat untuk menjelaskan dan mengambil kesimpulan mengenai hubungan motivasi kerja (X1) dan pengembangan karir $(\mathrm{Y})$. persamaan ini memiliki arti bahwa settiap kenaikan satu unit motivasi kerja akan meningkatkan unit pengembangan karir dengan konstanta 19,414.

Adapun kekuatan korelasi antara motivasi kerja dan pengembangan karir pegawai ditunjukkan dengan perhitungan koefisien korelasi dari rumus korelasi Product Moment $\left(\mathrm{ry}_{1}\right)$. Untuk mengetahui koefisien korelasi di atas signifikan atau tidak, dihgunakan uji t. rangkuman hasil pengujian korelasi seperti tampat pada tabel.

Dari hasil analisis uji t pada tabel, diperoleh $\mathrm{t}$ hitung sebesar 2,938 dan signifikansi nilai $\mathrm{t}$ sebesar 0,005 artinya terdapat hubungan yang positif antara variabel motivasi kerja dan pengembangan karir pegawai karena nilai signifikansi $t_{\text {hitung }}$ alpha $(0,05)$.

Uji F bertujuan untuk menguji signifikasi model regresi motivasi kerja (X1) terhadap pengembangan karir $(\mathrm{Y})$.hasil uji $\mathrm{F}$ seperti yang terdapat seperti berikut ini.

Uji F dilakukan untuk menguji hipotesis ini adalah:

$\mathrm{Ho}=0$; atau model regresi tidak signifikan

$\mathrm{Ha} \neq 0$; atau model regresi signifikan

Dasar pengambilan keputusan adalah:

Jika nilai signifikansi $F_{\text {hitung }}>$ alpha $(0,05)$ maka Ho tidak ditolak

Jika nilai signifikansi $F_{\text {hitung }}<$ alpha $(0,05)$ maka Ha ditterima, Ho ditolak

Melalui bantuan pengolahan komputer berdasarkan perhitungan SPSS 23.0 for windowsdengan signifikansi Fhitung sebesar 0,002. Dengan demikian nilai signifikansi $F$ hitung $<0,05$ sehingga jelas Ha diterima dan Ho ditolak. Hal ini menunjukkan bahwa model regresi variabel motivasi kerja signifikan terhadap variabel pengembangan karir. Artinya bahwa hipotesis yang mengatakan terdapat hubungan antara motivasi kerja dengan pengembangan karir diterima.

\section{b. Uji Hubungan keterampilan kerja $\left(X_{2}\right)$ terhadap pengembangan karir (Y)}

Tabel 3. Hasil Analisis Regresi Linier Sederhana Keterampilan Kerja Terhadap Pengembangan Karir

\section{Coefficients $^{\mathrm{a}}$}




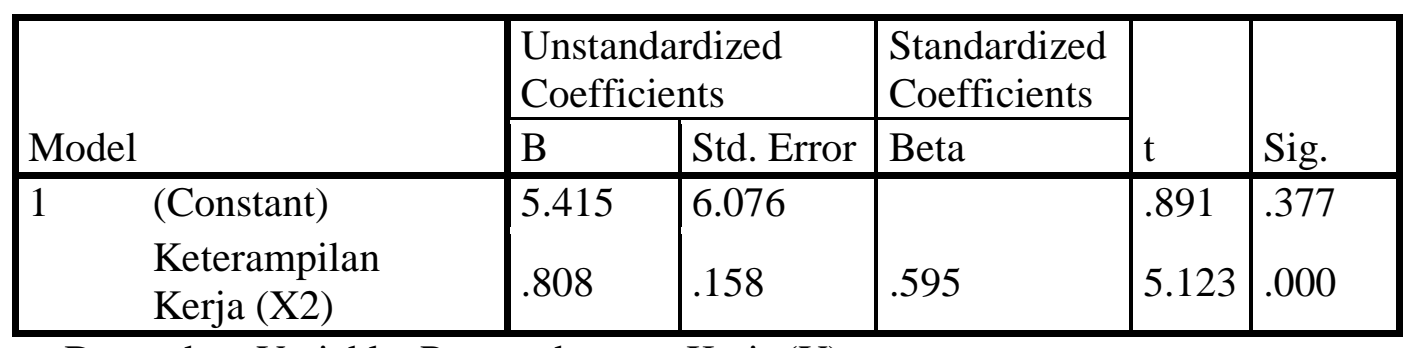

a. Dependent Variable: Pengembangan Karir (Y)

Sumber: data kusioner diolah dengan SPSS

Dari hasil tersebut dapat dismpulkan bahwa korelasi antara keterampilan kerja dan pengembangan karir pegawai signifikan. Artinya persamaan regresi $\hat{Y}=5,415+0,808 . X_{2}$ dapat digunakan sebagai alat untuk menjelaskan dan mengambil kesimpulan mengenai hubungan keterampilan kerja (X2) dan pengembangan karir (Y). Persamaan ini memiliki arti bahwa setiap kenaikan satu unit keterampilan kerja akan meningkatkan pengembangan karir dengan konstanta 5,415.

Adapun kekuatan korelasi antara keterampilan kerja dan pengembangan karir pegawai ditunjukkan dengan perhitungan koefisien korelasi dari rumus korelasi Product Moment ( $\left.\mathrm{ry}_{1}\right)$. Untuk mengetahui koefisien korelasi di atas signifikan atau tidak, dihgunakan uji t. rangkuman hasil pengujian korelasi seperti tampat pada tabel.

Dari hasil analisis uji t pada tabel, diperoleh $\mathrm{t}$ hitung sebesar 5,123 dan signifikansi nilai $\mathrm{t}$ sebesar 0,000 artinya terdapat hubungan yang positif antara variabel keterampilan kerja dan pengembangan karir pegawai karena nilai signifikansi $\mathrm{t}_{\text {hitung }}<$ alpha $(0,05)$.

Uji $F$ bertujuan untuk menguji signifikasi model regresi keterampilan kerja (X2) terhadap pengembangan karir (Y). hasil uji F seperti yang terdapat seperti berikut berikut ini.

Uji F dilakukan untuk menguji hipotesis ini adalah:

$\mathrm{Ho}=0$; atau model regresi tidak signifikan

$\mathrm{Ha} \neq 0$; atau model regresi signifikan

Dasar pengambilan keputusan adalah:

Jika nilai signifikansi $F_{\text {hitung }}>$ alpha $(0,05)$ maka Ho tidak ditolak

Jika nilai signifikansi $\mathrm{F}_{\text {hitung }}<$ alpha $(0,05)$ maka Ha ditterima, Ho ditolak

Melalui bantuan pengolahan komputer berdasarkan perhitungan SPSS 23.0 for windows dengan signifikansi Fhitung sebesar 0,002. Dengan demikian nilai signifikansi $\mathrm{F}$ hitung $<0,05$ sehingga jelas $\mathrm{Ha}$ diterima dan Ho ditolak. Hal ini menunjukkan bahwa model regresi variabel keterampilan kerja signifikan terhadap variabel pengembangan karir. Artinya bahwa hipotesis yang mengatakan terdapat hubungan antara keterampilan kerja dengan pengembangan karir diterima. 


\section{c. Uji Hubungan perilaku kognitif $\left(X_{3}\right)$ terhadap pengembangan karir}

(Y)

\section{Tabel 4. Hasil Analisis Regresi Linier Sederhana Perilaku Kognitif Terhadap Pengembangan Karir}

Coefficients $^{\mathrm{a}}$

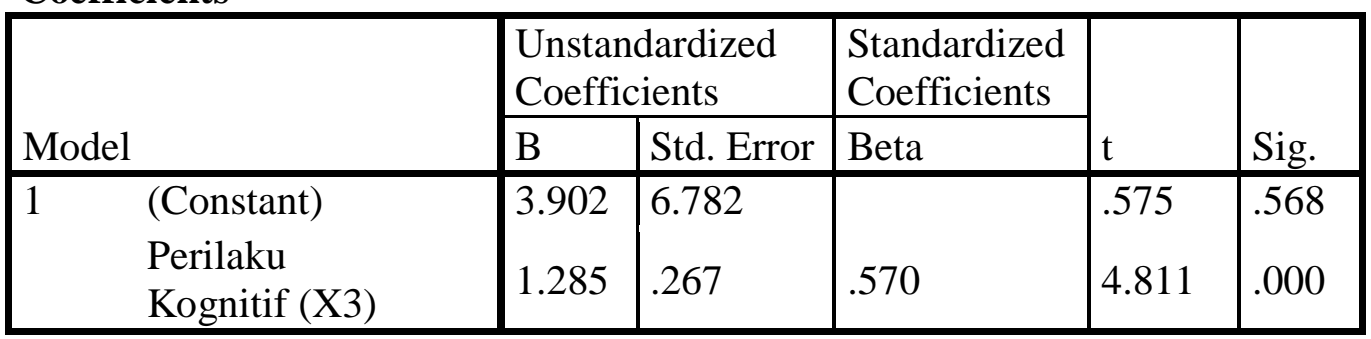

a. Dependent Variable: Pengembangan Karir (Y)

Sumber: data kusioner diolah dengan SPSS

Dari hasil tersebut dapat disimpulkan bahwa korelasi antara perilaku kognitif sebagai variabel kontrol dan pengembangan karir pegawai signifikan. Artinya persamaan regresi $\hat{Y}=3,902+1,285 . X_{3}$ dapat digunakan sebagai alat untuk menjelaskan dan mengambil kesimpulan mengenai hubungan perilaku kognitif (X3) dan pengembangan karir (Y). persamaan ini memiliki arti bahwa settiap kenaikan satu unit keterampilan kerja akan meningkatkan pengembangan karir dengan konstanta 3.902.

Adapun kekuatan korelasi antara perilaku kognitif dan pengembangan karir pegawai ditunjukkan dengan perhitungan koefisien korelasi dari rumus korelasi Product Moment $\left(\mathrm{ry}_{1}\right)$. Untuk mengetahui koefisien korelasi di atas signifikan atau tidak, dihgunakan uji t. rangkuman hasil pengujian korelasi seperti tampak pada tabel.

Dari hasil analisis uji $\mathrm{t}$ pada tabel, diperoleh $\mathrm{t}$ hitung sebesar 4,811 dan signifikansi nilai $t$ sebesar 0,000 artinya terdapat hubungan yang positif antara variabel perilaku kognitif dan pengembangan karir pegawai karena nilai signifikansi $\mathrm{t}_{\text {hitung }}<$ alpha $(0,05)$.

Uji F bertujuan untuk menguji signifikasi model regresi perilaku kognitif (X3) terhadap pengembangan karir (Y). hasil uji F seperti yang terdapat seperti berikut ini.

Uji F dilakukan untuk menguji hipotesis ini adalah:

$\mathrm{Ho}=0$; atau model regresi tidak signifikan

$\mathrm{Ha} \neq 0$; atau model regresi signifikan

Dasar pengambilan keputusan adalah:

Jika nilai signifikansi $\mathrm{F}_{\text {hitung }}>$ alpha $(0,05)$ maka Ho tidak ditolak

Jika nilai signifikansi $\mathrm{F}_{\text {hitung }}<$ alpha $(0,05)$ maka Ha ditterima, Ho ditolak 
Melalui bantuan pengolahan computer berdasarkan perhitungan SPSS 23.0 for windows dengan signifikansi Fhitung sebesar 0,000. Dengan demikian nilai signifikansi $\mathrm{F}$ hitung $<0,05$ sehingga jelas Ha diterima dan Ho ditolak. Hal ini menunjukkan bahwa model regresi variabel perilaku kognitif signifikan terhadap variabel pengembangan karir. Artinya bahwa hipotesis yang mengatakan terdapat hubungan antara perilaku kognitif dengan pengembangan karir diterima.

\section{d. Uji Hubungan motivasi kerja $\left(X_{1}\right)$, keterampilan kerja $\left(X_{2}\right)$ dan perilaku kognitif (X3) terhadap pengembangan karir (Y)}

Tabel 5. Hasil Uji Analisis Regresi Linier Berganda

\begin{tabular}{|c|c|c|c|c|c|c|}
\hline \multicolumn{7}{|c|}{ Coefficients $^{\mathrm{a}}$} \\
\hline \multirow{2}{*}{\multicolumn{2}{|c|}{ Model }} & \multicolumn{2}{|c|}{$\begin{array}{l}\text { Unstandardized } \\
\text { Coefficients }\end{array}$} & \multirow{2}{*}{$\begin{array}{l}\text { Standardized } \\
\text { Coefficients } \\
\text { Beta } \\
\end{array}$} & \multirow[b]{2}{*}{$t$} & \multirow[b]{2}{*}{ Sig. } \\
\hline & & $\mathrm{B}$ & Std. Error & & & \\
\hline \multirow[t]{4}{*}{1} & (Constant) & -2.013 & 6.893 & & -.292 & .772 \\
\hline & $\begin{array}{l}\text { Perilaku } \\
\text { Kognitif (X3) }\end{array}$ & .746 & .345 & .331 & 2.161 & .036 \\
\hline & $\begin{array}{l}\text { Keterampilan } \\
\text { Kerja (X2) }\end{array}$ & .545 & .214 & .401 & 2.546 & .014 \\
\hline & $\begin{array}{l}\text { Motivasi } \\
\text { Kerja (X1) }\end{array}$ & -.038 & .176 & -.031 & -.216 & .830 \\
\hline
\end{tabular}

a. Dependent Variable: Pengembangan Karir (Y)

Sumber: Data angket diolah dengan SPSS

Dari tabel di atas menunjukkan nilai konstanta untuk variabel motivasi kerja, keterampilan kerja dan perilaku kognitf sebesar -2,013 sedangkan nilai koefisien motivasi kerja sebesar -0,380, nilai koefisien keterampilan kerja sebesar 0,545 dan nilai koefisiensi perilaku kognitif sebesar 0,746. Karena nilai koefisien regresi bernilai positif (+), maka dengan demikian keterampilan kerja dan perilaku kognitif memberikan hubungan positif terhadap pengembangan karir.

Selanjutnya untuk memastikan apakah koefisien regresi linier berganda berhubungan antara variabel kompensasi dan komitmen organisasi secara bersama-sama terhadap kinerja guru dilakukan uji signifikansi melalui ujiF pada taraf $0,05 \%$. Dengan bantuan tabel Anova hasil dari pengolahan data dengan program SPSS versi 23.0 diperoleh data seperti disajikan dalam tabel di bawah ini: 
Tabel 6. Hasil Uji F Variabel Motivasi Kerja, Keterampilan Kerja dan Perilaku Kognitif Organisasi Secara Simultan

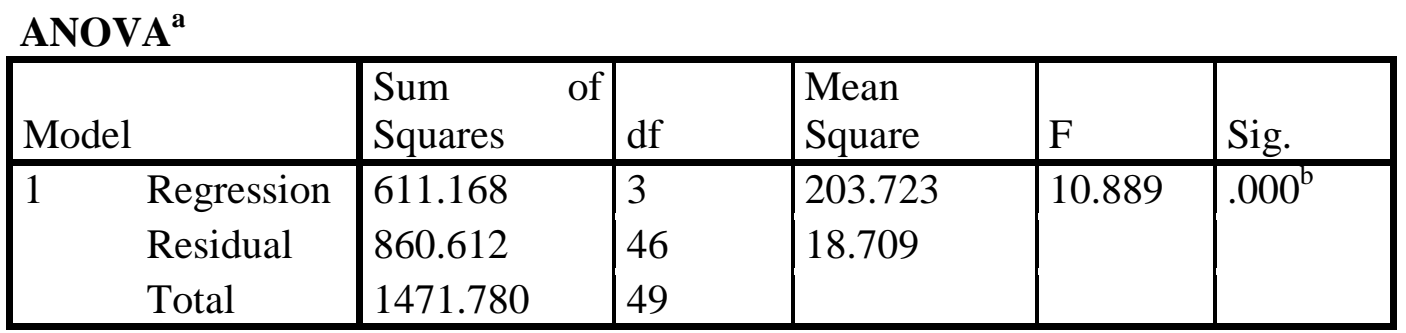

a. Dependent Variable: Pengembangan Karir (Y)

b. Predictors: (Constant), Motivasi Kerja (X1) , Perilaku Kognitif (X3), Keterampilan Kerja (X2)

Sumber: Data angket diolah dengan SPSS

- Berdasarkan Nilai Signifikansi (Sig.) dari output Anova

Berdasarkan tabel output di atas, diketahui nilai Sig. adalah sebesar 0,000. Karena nilai Sig. $<0,05$, maka sesuai dengan dasar pengambilan keputusan dalam uji $\mathrm{F}$ dapat disimpulkan bahwa hipotesis diterima atau dengan kata lain motivasi kerja (X1), keterampilan kerja (X2) dikontrol oleh perilaku kognitif (X3) secara simultan berhubungan terhadap pengembangan karir (Y).

- Berdasarkan Perbandingan Nilai F Hitung dengan F Tabel

Berdasarkan tabel output di atas, diketahui nilai $\mathrm{F}$ hitung adalah sebesar 10,889. Karena nilai F hitung 10,889 > F tabel 2,79, maka sebagaimana dasar pengambilan keputusan dalam uji $\mathrm{F}$ dapat disimpulkan bahwa hipotesis diterima atau dengan kata lain motivasi kerja (X1), keterampilan kerja (X2) dan perilaku kognitif (X3) secara simultan berhubungan terhadap pengembangan karir (Y).

\section{PEMBAHASAN}

Berdasarkan hasil penelitian yang dilakukan antara lain:

1. Terdapat hubunganantara motivasi kerja dengan pengembangan karir. Dari

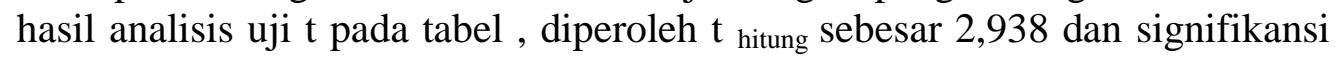
nilai $\mathrm{t}$ sebesar 0,005 artinya terdapat hubungan yang positif antara variabel motivasi kerja dan pengembangan karir pegawai karena nilai signifikansi $t$ hitung < alpha $(0,05)$.

2. Terdapat hubungan antara keterampilan kerja terhadap pengembangan karir. Dari hasil analisis uji $\mathrm{t}$ pada tabel, diperoleh $\mathrm{t}$ hitung sebesar 5,123 dan signifikansi nilai t sebesar 0,000 artinya terdapat hubungan yang positif antara variabel keterampilan kerja dan pengembangan karir pegawai karena nilai signifikansi $\mathrm{t}_{\text {hitung }}$ alpha $(0,05)$.

3. Terdapat hubungan antara perilaku kognitif terhadap pengembangan karir. Dari hasil analisis uji $\mathrm{t}$ pada tabel, diperoleh $\mathrm{t}$ hitung sebesar 4,811 dan signifikansi nilai t sebesar 0,000 artinya terdapat hubungan yang positif antara variabel perilaku kognitif dan pengembangan karir pegawai karena nilai signifikansi $\mathrm{t}_{\text {hitung }}<$ alpha $(0,05)$. 
4. Berdasarkan tabel output pada tabel 4.22 diketahui nilai Sig. adalah sebesar 0,000. Karena nilai Sig. $<0,05$, maka sesuai dengan dasar pengambilan keputusan dalam uji $\mathrm{F}$ dapat disimpulkan bahwa hipotesis diterima atau dengan kata lain motivasi kerja (X1), keterampilan kerja (X2) dan perilaku kognitif (X3) secara simultan berhubungan terhadap pengembangan karir (Y)

\section{E. KESIMPULAN}

1. Terdapat hubungan positif dan signifikan antara Motivasi Kerja (X1) dengan Pengembangan Karir (Y) di Satpol PP Kecamatan Kebayoran Baru Kota Administrasi Jakarta Selatan. Hal ini terlihat dari hasil koefisien korelasi (R) sebesar 0,390, dengan persamaan regresi $\hat{Y}=19,414+0,471 . X_{1}$, hasil uji $T$ diperoleh $t_{\text {hitung }}$ sebesar 2,938 dan Sig nilai $t$ sebesar 0,005 ( $t_{\text {hitung }}$ <alpha 0,05$)$.

2. Terdapat hubungan positif dan signifikan antara Keterampilan Kerja (X2) dengan Pengembangan Karir (Y) di Satpol PP Kecamatan Kebayoran Baru Kota Administrasi Jakarta Selatan.Hal ini terlihat dari hasil koefisien korelasi (R) sebesar 0,595, dengan persamaan regresi $\hat{Y}=5,415+0,808 . X_{2}$, hasil uji $\mathrm{T}$ diperoleh $t_{\text {hitung }}$ sebesar 5,123 dan Sig nilai $t$ sebesar 0,000 ( $\left.t_{\text {hitung }}<a l p h a 0,05\right)$.

3. Terdapat hubungan positif dan signifikan antara Perilaku Kognitif (X3) dengan Pengembangan Karir (Y) di Satpol PP Kecamatan Kebayoran Baru Kota Administrasi Jakarta Selatan.Hal ini terlihat dari hasil koefisien korelasi (R) sebesar 0,570, dengan persamaan regresi $\hat{Y}=3,902+1,285 . X_{3}$, hasil uji $\mathrm{T}$ diperoleh $t_{\text {hitung }}$ sebesar 4,811 dan Sig nilai t sebesar 0,000 ( $t_{\text {hitung }}<$ alpha 0,05 ).

4. Terdapat hubungan yang positif dan signifikan antara Motivasi Kerja (X1), Keterampilan Kerja (X2) dan Perilaku Kognitif (X3) secara bersama-sama dengan Pengembangan Karir (Y) dengan korelasi ganda sebesardi Satpol PP Kecamatan Kebayoran Baru Kota Administrasi Jakarta Selatan. Hal ini terlihat dari hasil koefisien korelasi (R) sebesar 0,644.

\section{F. IMPLIKASI}

Berdasarkan model penelitian yang dikembangkan dalam penelitian ini, maka dapat memperkuat konsep-konsep teoritis dan memberikan dukungan empiris terhadap penelitian terdahulu. Literatur-literatur yang menjelaskan tentang Motivasi Kerja, Keterampilan Kerja dan Perilaku Kognitif pada Pengembangan Karir telah diperkuat keberadaannya oleh konsep-konsep teoritis dan dukungan empiris mengenai hubungan kausalitas dan variabel-variabel yang memiliki hubungan manajemen sumber daya manusia yang tepat. Selanjutnya Manajemen Sumber Daya Manusia akan mempengaruhi Pengembangan Karir Pegawai. Beberapa hal penting yang berhubungan dengan implikasi teoritis dapat dijelaskan sebagai berikut:

1. Keberhasilan organisasi mencapai tujuannya tidak terlepas dari pengembangan karir masing-masing individu yang ada di dalamnya sebagai pelaku pencapaian tujuan organisasi. Pengembangan karir merupakan pelaksanaan dan usaha pegawai untuk meningkatkan karirnya dalam rangkaian posisi pekerjaan untuk mendapatkan tanggung jawab, wewenang, dan jenis-jenis tugas yang semakin besar, dimana dalam penelitian ini 
memfokuskan analisa penelitian pada faktor motivasi kerja, keterampilan kerja dan perilaku kognitif.

2. Hasil penelitian menunjukan bahwa pengembangan karir di Satuan Polisi Pamong Praja Kecamatan Kebayoran Baru Kota Administrasi Jakarta Selatan secara umum belum mencapai kondisi terbaik sehingga masih perlu ditingkatkan lagi untuk mencapai keberhasilan/ tujuan organisasi yang optimal,terutama dalam merumuskan sistem pengembangan karir dan promosi/ kenaikan jabatan.

3. Dalam merumuskan sistem pengembangan karir dan promosi/ kenaikan jabatan, maka Satuan Polisi Pamong Praja Kecamatan Kebayoran Baru Kota Administrasi Jakarta Selatan perlu memperhatikan dimensi-dimensi yang masih memerlukan pembinaan dari masing-masing variabel motivasi kerja, keterampilan kerja dan perilaku kognitif.

4. Pimpinan di Satuan Polisi Pamong Praja Kecamatan Kebayoran Baru Kota Administrasi Jakarta Selatan perlu lebih mendorong lagi peningkatan motivasi kerja individu pada peagawainya dengan mensosialisasikan dan memberikan pengarahan yang lebih jelas tentang visi dan misi organisasi kepada seluruh pegawai, serta menjabarkannya secara lebih operasional dan mengkaitkan pencapaian visi dan misi organisasi tersebut dengan sasaran dan target kerja yang harus dicapai oleh setiap pegawai sehingga visi dan misi terebut dapat dipahami dengan jelas dan tertanam dalam diri setiap pegawai dan dengan demikian pegawai akan melaksanakan tugas-tugasnya secara lebih sungguhsungguh. Disamping itu setiap Pimpinan harus dapat lebih meningkatkan perhatiannya pada perencanaan pengembangan karir pegawai sehingga program kerja yang dilaksanakan, khsususya yang terkait dengan pengembangan SDM dapat lebih terarah, berkesinambungan, dan dapat mengikuti perubahan lingkungan dan tuntutan kebutuhan masyarakat daerah Jakarta.

\section{DAFTAR PUSTAKA}

Anderson, Gordon C. (1993). Managing Performance Appraisal Systems. London, UK : Blackwell Publisher.

B. Uno, Hamzah. (2008). Teori Motivasi dan Pengukurannya. Jakarta : Bumi Aksara. BSNP

Danang, Sunyoto. (2012). Manajemen Sumber Daya Manusia. Indonesia : Gudang Penerbit.

Dunette. (1976). Menemukan Potensi Yang Terdalam. Magelang : Geger Sunten.

Dessler, Gary. (2014). Manajemen SumberDaya Manusia (Edisilo : Terjemahan Indonesia). Jakarta: Indeks.

Flippo. (2014). Manajemen Personalia. Jakarta. : PT. Gelora Askara Pratma

Gibson, James L., Ivancevich, John M., dan Donnelly, James H., Jr. (2010). Organisasi (AlihBahasa: NunukAdiarni). Tangerang: Binarupa Aksara. 
Ghozali, Imam. (2013). Aplikasi Analisis Multivariate dengan Program SPSS. Edisi Ketujuh. Semarang. Badan Penerbit Universitas Diponegoro.

Hasibuan, Malayu S.P. (2006). Manajemen Sumber Daya Manusia. Jakarta : Edisi Revisi, Bumi Aksara.

Soekidjo. 1997. Ilmu Kesehatan Masyarakat.Jakarta : Rineka Cipta.

Hall and Goodale. (1986). Human Resource Management. U.S.A. : Scott Foresman \& Co.

Iverson. (2001). Memahami Keterampilan Pribadi. Bandung : CV. Pustaka.

Jamaris. (2006). Perkembangan dan Pengembangan Anak Usia Taman Kanak-kanak. Jakarta : Gramedia.

M. Sopiyudin Dahlan. (2010). Statistik untuk Kedokteran dan Kesehatan. Jakarta : Salemba Medika.

Miner, John B., and Donald P. Crane. (1995). Human Resource Management: The Strategic Perspective, USA : HarperCollin College Publishers.

Mondy, Wayne R. (2015). ManajemenSumberDayaManusia (Edisi X, Jilid 2). Jakarta: Penerbit .

Naddler. (1986). Keterampilan dan Jenisnya. Jakarta : PT. Grapindo Persada.

Ngalim, Purwanto. (2012). Psikologi Pendidikan. Bandung : Remaja Rosdakarya.

Notoatmodjo, Soekidjo. (2003). Pendidikan Dan Perilaku Kesehatan. Jakarta : Rineka Cipta. Jakarta.

Noe R, M. (1996). Human Resource Managemet. Texas : Prentice Hall, Inc.

Robbins, S.P., and Mary Coulter. (2007). Management $\left(9^{\text {th }}\right.$ edition). Pearson International Edition.

Robbins, P.Stephen dan Timothy A. Judge. (2010). Perilaku Organisasi. Salemba Empat. Jakarta.

Sarwono, W. Sarlito. (2004). Psikologi remaja. Jakarta. PT RajaGrafindo Persada.

Simamora.Henry. (2004). Manajemen Sumber Daya Manusia. (Yogyakarta: SIE YKPN).

Sugiyono. (2008). Metode Penelitian Pendidikan. Bandung : Penerbit Alfabeta.

Sunyoto. (2012). Manajemen Sumber Daya Manusia, Yogyakarta : CAPS.

Suryana. (2015). Metode Penelitian. Bandung : CV Pustaka Setia.

Tampubolon, Manahan. (2012). Perilaku Keorganisasian. Bogor : Ghalia Indonesia.

T. Hani Handoko. (2011). Manajemen, Edisi Kedua, Yogyakarta : BPFEYOGYAKARTA.

Wherther, Jr., and Davis. (1996), Career development consists of the personal improvement one undertakes to achieve a personal career plan.

Sumber Internet :

https://www.youtube.com/watch?v=Whb6nt4CNHM

Sahid Raharjo, S.Pd :www.spssindonesia.com.

Jurnal :

https://www.researchgate.net/journal/10991379_Journal_of_Organizational_Behavior 
